\title{
Potential Protective Mechanisms of Ketone Bodies in Migraine Prevention
}

\author{
Elena C. Gross ${ }^{1, *}$, Rainer J. Klement ${ }^{2}{ }^{-}$, Jean Schoenen ${ }^{3} \odot$, Dominic P. D'Agostino ${ }^{4,5}$ and \\ Dirk Fischer ${ }^{1}$ \\ 1 Division of Paediatric Neurology, University Children's Hospital Basel (UKBB), University of Basel, \\ 4056 Basel, Switzerland; dirk.fischer@ukbb.ch \\ 2 Department of Radiation Oncology, Leopoldina Hospital Schweinfurt, 97422 Schweinfurt, Germany; \\ rainer_klement@gmx.de \\ 3 Headache Research Unit, University of Liège, Dept of Neurology-Citadelle Hospital, 4000 Liège, Belgium; \\ jschoenen@uliege.be \\ 4 Department of Molecular Pharmacology and Physiology, Metabolic Medicine Research Laboratory, \\ Morsani College of Medicine, University of South Florida, Tampa, FL 33612, USA; ddagosti@health.usf.edu \\ 5 Institute for Human and Machine Cognition, Ocala, FL 34471, USA \\ * Correspondence: elena.gross@oxfordalumni.org
}

Received: 12 March 2019; Accepted: 8 April 2019; Published: 10 April 2019

check for updates

\begin{abstract}
An increasing amount of evidence suggests that migraines are a response to a cerebral energy deficiency or oxidative stress levels that exceed antioxidant capacity. The ketogenic diet (KD), a diet mimicking fasting that leads to the elevation of ketone bodies (KBs), is a therapeutic intervention targeting cerebral metabolism that has recently shown great promise in the prevention of migraines. KBs are an alternative fuel source for the brain, and are thus likely able to circumvent some of the abnormalities in glucose metabolism and transport found in migraines. Recent research has shown that KBs-D- $\beta$-hydroxybutyrate in particular-are more than metabolites. As signalling molecules, they have the potential to positively influence other pathways commonly believed to be part of migraine pathophysiology, namely: mitochondrial functioning, oxidative stress, cerebral excitability, inflammation and the gut microbiome. This review will describe the mechanisms by which the presence of KBs, D-BHB in particular, could influence those migraine pathophysiological mechanisms. To this end, common abnormalities in migraines are summarised with a particular focus on clinical data, including phenotypic, biochemical, genetic and therapeutic studies. Experimental animal data will be discussed to elaborate on the potential therapeutic mechanisms of elevated KBs in migraine pathophysiology, with a particular focus on the actions of D-BHB. In complex diseases such as migraines, a therapy that can target multiple possible pathogenic pathways seems advantageous. Further research is needed to establish whether the absence/restriction of dietary carbohydrates, the presence of KBs, or both, are of primary importance for the migraine protective effects of the KD.
\end{abstract}

Keywords: migraine; beta-hydroxybutyrate; ketone bodies; ketosis; migraine prevention; ketogenic diet; exogenous ketone bodies

\section{Introduction}

Migraine is a complex, common and debilitating neurological disorder [1]. Its episodic form is characterized by recurrent moderate to severe, typically throbbing and unilateral headache attacks that last between $4-72 \mathrm{~h}$, which are aggravated by any kind of physical activity and accompanied by either photo-, phono-, or osmophobia, nausea, or a combination of these. Migraine affects approximately $17 \%$ of women and $8 \%$ of men in Europe [2], and with a peak incidence during the most productive 
years of life, migraine not only causes a huge amount of suffering, but also inflicts a substantial number of costs on society: approximately $€ 18.5$ billion per year in Europe alone [3,4]. Current migraine treatment options have limited efficacy and many-often intolerable-side-effects $[5,6]$, with the potential exception of the very recent addition of monoclonal Calcitonin gene-related peptide (CGRP) antibodies [7]. Despite migraine's primary pathogenic mechanisms being still largely unknown [8], accumulating evidence suggests that migraines could be—at least partially—an energy deficit syndrome of the brain, and the migraine attack a response to increased oxidative stress and/or (cerebral) hypometabolism [9]. Therapeutic approaches targeting cerebral metabolism may be warranted.

Ketone bodies (KBs: D- $\beta$-hydroxybutyrate (D-BHB), acetoacetate (AcAc), and to a lesser extent acetone) are mainly produced by the liver, but also other tissues, such as astrocytes [10], when glycogen storage is deprived, to serve as energetic substrates in the absence or severe reduction of dietary glucose, in particular for the heart and the brain. Mimicking this state of fasting, the ketogenic $\operatorname{diet}(\mathrm{KD})$ promotes the hepatic production of KBs with a high fat, low carbohydrate and moderate protein content. It was developed about 100 years ago after the observation that prolonged fasting has anticonvulsive properties [11]. Within recent years, the KD has received renewed interest, in particular since KBs might be beneficial for a variety of other neurological disorders [12-14]. All brain cells have the capacity to use KBs as respiratory substrates [10].

Out of the three physiological KBs, D-BHB constitutes up to $70 \%$ of $\mathrm{KBs}$ produced during ketosis [15] and is of particular interest, since it is not only a glucose transporter protein, i.e., a (GLUT)-independent alternative metabolite, but also a vital signalling molecule [16]. Many of these collateral effects make it a molecule of interest for therapeutic purposes. During a standard Western diet, the blood concentration of D-BHB is very low $(<0.2 \mathrm{mmol} / \mathrm{L})$ compared to glucose ( $\cong 5 \mathrm{mmol} / \mathrm{L}$ ) [17]. During fasting or the KD D-BHB concentrations typically rise to levels between $0.5-5 \mathrm{mmol} / \mathrm{L}$ and up to $8 \mathrm{mmol} / \mathrm{L}$ during starvation [18]. Elevated KB levels have been shown to be well tolerated for extended periods of time (up to several years [19-32]).

Several case studies have demonstrated the potentially migraine protective effects of ketosis [22,33-37]. A one-month observational study of KD in 96 migraine patients as part of a weight loss program found a reduction of up to $80 \%$ in migraine frequency, severity and acute medication use [37]. The same intervention in 18 episodic migraineurs induced a $62.5 \%$ reduction in migraine days, which was accompanied by a normalization of the interictal habituation deficit of visual evoked responses [36]. The reduction in migraine attack frequency, severity and the use of acute anti-migraine medication during ketosis had effect sizes ranging from a total absence of attacks [33] to a reduction to $1 / 5$ th of the run-in period [37]. In addition, preliminary evidence suggests that the protective effect may outlast the duration of ketosis [33], as is often the case in pediatric epilepsy patients, and could be the result of longer-lasting gene-expression changes [12,38].

This review will describe the mechanisms by which the presence of ketone bodies, D-BHB in particular, could influence migraine pathophysiology (see Figure 1). To this end, common abnormalities in migraine (such as abnormalities in glucose metabolism and transport, mitochondrial functioning, oxidative stress, cerebral excitability, inflammation and the gut microbiome) are summarised with a particular focus on clinical data, including phenotypic, biochemical, genetic and therapeutic studies. Experimental animal data will be discussed to elaborate on the potential therapeutic mechanisms of elevated KBs in migraine pathophysiology with a particular focus on the actions of D-BHB. Please note that there is not enough research at present to disentangle the potentially differential effects of D-BHB within the scope of a KD (i.e., endogenous KBs via restriction of dietary carbohydrates) versus D-BHB added to a standard Western diet (i.e., exogenous BHB in addition to dietary carbohydrates). Research studies using either method will be cited, but not contrasted. 


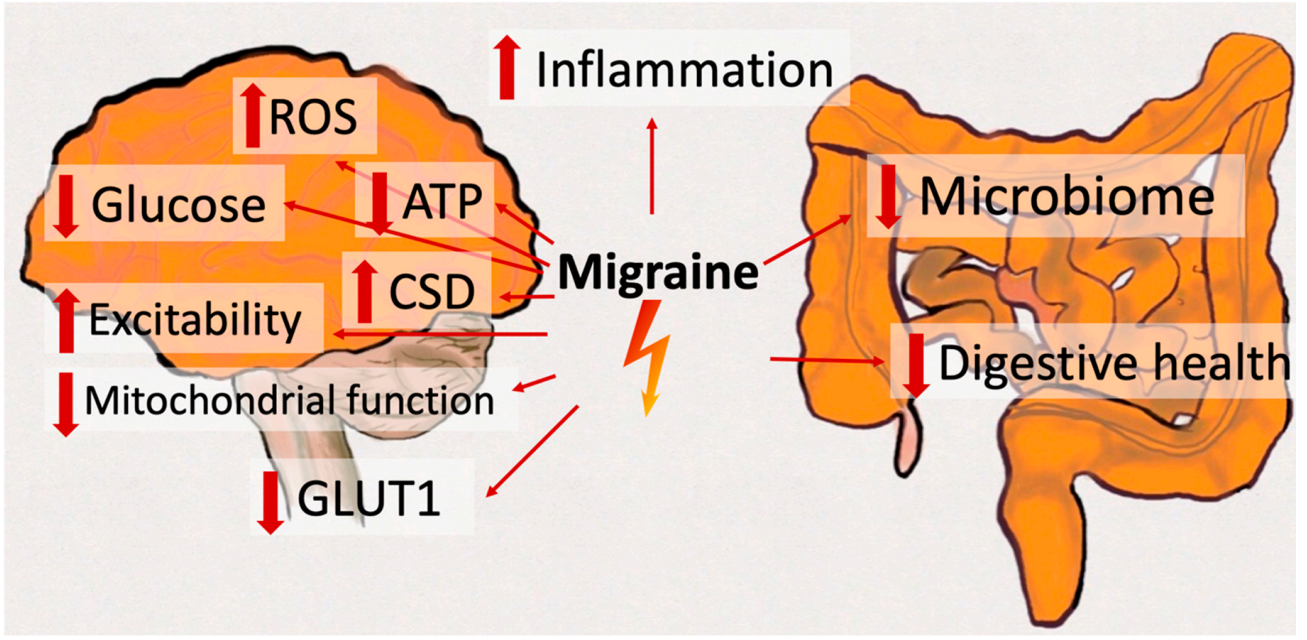

(a)

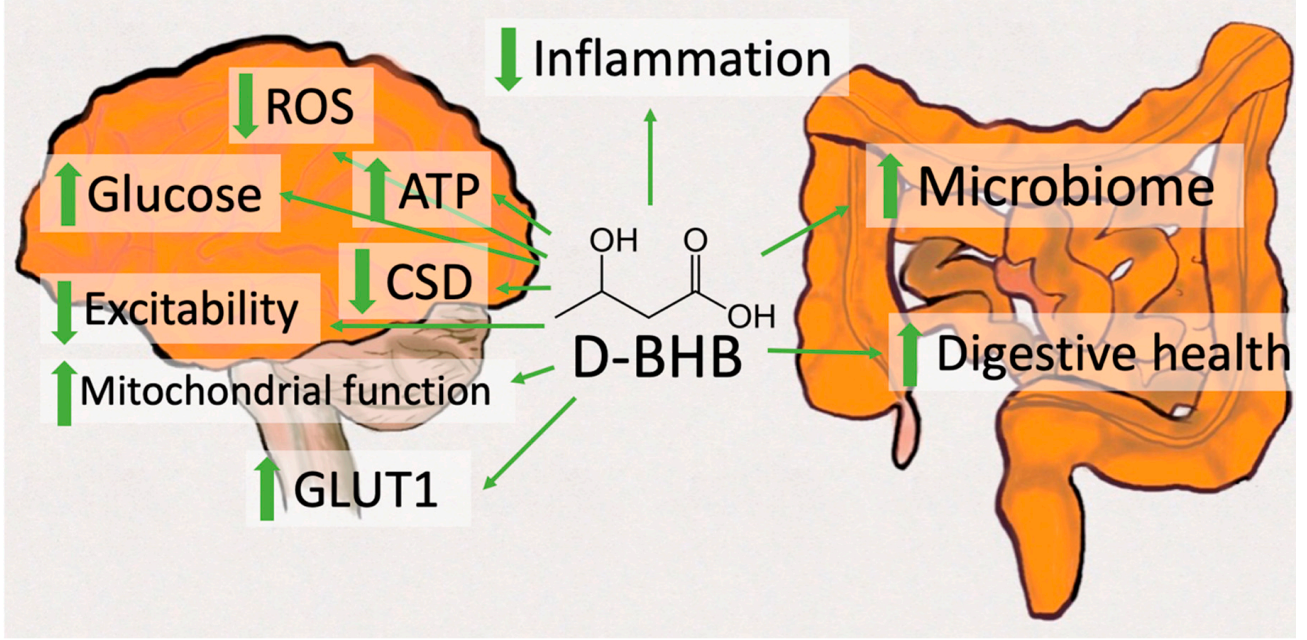

(b)

Figure 1. Potentially migraine relevant mechanisms of ketosis. (a) Amongst key migraine pathophysiological mechanisms are hypometabolism, decreased glucose transport (including glucose transporter 1 (GLUT1) deficiency), reduced mitochondrial functioning, increased cerebral excitability, increased cortical spreading depressions (CSD) incidence, increased oxidative stress (reactive oxygen species (ROS)), increased inflammation, microbiome abnormalities and reduced digestive health. (b) D- $\beta$-hydroxybutyrate (D-BHB; with or without the context of a ketogenic diet) has been shown to positively influence each of these mechanisms: increasing cerebral metabolism, increasing glucose transport (including glucose transporter 1 (GLUT1) deficiency), increasing mitochondrial functioning, reducing cerebral excitability, decreasing cortical spreading depressions (CSD) incidence, reducing oxidative stress (reactive oxygen species (ROS)), decreasing inflammation, improving the microbiome and increasing digestive health. ATP = adenosine triphosphate; $\mathrm{CSD}=$ cortical spreading depressions; $\mathrm{D}$-BHB = D- $\beta$-hydroxybutyrate; GLUT1 = glucose transporter $1 ;$ ROS = reactive oxygen species.

\section{Potentially Migraine Relevant Mechanisms of Ketosis}

\subsection{Hypoglycemia/Hypometabolism}

Hypoglycaemia has been associated with migraine for almost a century [39-41] and fasting/skipping a meal is not only amongst the most commonly cited migraine triggers [42-44], but it can also be used experimentally to elicit migraine attacks in susceptible patients [39]. Due to very limited glycogen stores and high energy demands, the human brain is highly dependent on fuel sources from the circulation that can pass the blood-brain barrier and especially vulnerable to their 
potential short-comings. A simple comparison between migraine associated symptoms, premonitory symptoms in particular, and symptoms of hypoglycaemia [45] show several similarities: for example, dizziness, pale skin, cold hands and feet, binge eating/sugar cravings, yawning, nausea, low blood pressure, shaking, cognitive difficulties, tiredness, fatigue, visual dysfunction and slurred speech. Increased migraine frequency has also been observed during Ramadan [46] and migraine prevalence in type 2 diabetics was shown to proportionally increase with the number of hypoglycaemia attacks [47].

Further support for the role of energy deficiency and/or glucose metabolism in migraine comes from neuroimaging studies. Using 31P-MRS, an impairment of brain oxidative phosphorylation (OXPHOS) was detected first during migraine attacks [48] and thereafter between attacks [49-56]. OXPHOS abnormalities in patients with migraine were found both in the resting brain and in the muscle following exercise $[49,56,57]$ (review by [54]), where a reduced glycolytic flux could be demonstrated [49,51]. More recently, a 16\% decrease of absolute ATP levels in migraine without aura patients was demonstrated interictally using 31P-MRS [58]. This hypometabolism is generally found to moderately correlate with attack frequency $[52,56,58]$. A recent study comparing resting cerebral glucose uptake using 18-fluorodeoxyglucose-PET and visual cortex activation using visual evoked potentials showed that visual neuronal activation exceeded glucose uptake in visual areas in $90 \%$ of interictal migraine without aura patients, but in only $15 \%$ of healthy controls [59]. This supports the concept that a mismatch between brain activity and glucose metabolism may be a cornerstone of migraine pathophysiology.

KBs are known to be able to counteract some of the negative effects of hypoglycemia and/or hypometabolism or prevent it all together. D-BHB has been shown to efficiently prevent neuronal death in the cortex of hypoglycemic animals and in vitro it was found to stimulate ATP production in glucose deprived cortical cultures [60]. Glycolysis is reduced in the presence of D-BHB and ketosis proportionally spares glucose utilization in the brain [61,62]. When present in sufficient concentration to saturate metabolism, D-BHB provides full support of all basal (housekeeping) energy needs and up to approximately half of the activity-dependent oxidative needs of neurons in $36 \mathrm{~h}$ fasted rats [63]. Not only is D-BHB an alternative fuel source for the brain, it also seems to be more efficient. When catabolized for the synthesis of ATP in mitochondria, D-BHB produces more ATP per oxygen molecule consumed than many other respiratory substrates [64] and general "positive" shifts in energy balance have been observed [65-67].

There is circumstantial evidence from early experimental studies that oral glucose tolerance tests after an overnight fast can elicit migraine attacks in susceptible patients [68,69]. Interestingly, the metabolic responses in patients who developed an attack differed substantially from those that did not: free fatty acid (FFA) and KB levels increased significantly in the former, already before headache onset, and kept increasing despite similar food intake $[68,69]$. This can be interpreted as a counter-regulatory response to a cerebral energy deficit. Since KBs are an efficient alternative fuel for the brain, when glucose availability is low, their elevation would be expected to restore brain energy homeostasis, if present in sufficient quantity.

\subsection{Glucose Transport}

GLUTs are a wide group of membrane proteins that facilitate the transport of glucose across a plasma membrane. GLUT1 is an insulin-independent glucose transporter responsible for transporting glucose under basal conditions in all cells. This is especially the case in endothelial cells of the blood brain barrier as well as astrocytes and oligodendrocytes. In addition to glucose utilization, glucose transport might also play a role in migraine. GLUT1 deficiency syndrome has been linked to hemiplegic migraine and migraine with aura [70].

GLUT4 (adipose tissue and striated muscle) and GLUT3 (neuronal and glial cells) are the major insulin-mediated glucose transporters [71]. Insulin is the main anabolic hormone of the body and the key regulator of glucose homeostasis. It promotes the absorption of glucose from the blood and simultaneously blocks carnitine transporters and thus the penetration of FFA into the cells. 
Interictal impaired glucose tolerance and insulin resistance in migraine has been reported in various studies [72-76], but the evidence is not always conclusive [77]; see also the review by [78]. Some genetic support for a potential role of insulin in migraine comes from associations between polymorphisms in insulin-related genes and migraine [79-82].

KBs are taken up in to the brain via the monocarboxylate transporters (MCTs) and are hence completely GLUT and insulin independent. This KB transport mechanism allows the body and brain access to fuel even when glucose transport (GLUT1 or GLUT3/4) is compromised. Furthermore, KBs can also be produced endogenously in brain by astrocytes that have the capacity to metabolize free fatty acids and ketogenic amino acids L-Lysine and L-Leucine [10,83,84]. A strict KD can lead to complete remission in GLUT1 deficiency syndrome [85]. Additionally, a KD has been shown to lead to a marked upregulation of both GLUT1 and MCTs [86], thereby further enhancing available energy to the brain in a not completely GLUT1 compromised individual.

\subsection{Mitochondrial Functoning}

Several lines of evidence point towards a role of mitochondrial functioning in migraine. The prevalence of migraine in mitochondrial disorders is more than doubled $(29-35.5 \%$ of patients) $[87,88]$ and migraine-like attacks in Mitochondrial encephalomyopathy, lactic acidosis, and stroke-like episodes (MELAS) are especially severe and prolonged [89]. Maternal transmission in migraine is more common [90], which suggests that either an X-linked form of inheritance could be involved or that mitochondrial DNA (mtDNA) transmission plays a role, since mtDNA derives exclusively from maternal origin. Furthermore, enrichment of a migraine genome-wide association study (GWAS) signal was found for mitochondria in both subcortical areas and the cortex (amongst others), a finding that identifies a genetic link between mitochondrial function and common migraine [91].

Further support for a generalized metabolic dysfunction in migraine comes from the reduced activity of mitochondrial enzymes, such as monoamine-oxidase, succinate-dehydrogenase, $\mathrm{NADH}$-dehydrogenase, cyclooxygenase (COX) and citrate-synthetase in the platelets of migraine patients with and without aura [92,93]. Interestingly, these biochemical changes are restricted to enzymes of the respiratory chain that are encoded by mtDNA. In contrast to nuclear DNA, mtDNA is particularly sensitive to ROS because it lacks protection from histones [94,95].

Therapeutic studies also support mitochondrial dysfunction in migraine. Most nutraceuticals that have been demonstrated to be migraine preventative can directly be linked to energy metabolism and / or mitochondrial functioning, such as: high dose riboflavin (200-400 mg) [96-100], coenzyme Q10 (400 mg capsules or $300 \mathrm{mg}$ liquid suspension) [101-106], alpha-lipoic acid (or thioctic acid) [107-109], B vitamins [110-112] and magnesium [113]. Even pharmaceutical prophylactic agents used against migraine are able to influence mitochondrial functioning and metabolism. For example, Topiramate prolongs mitochondrial survival, increases the activity of the mitochondrial respiratory chain complex [114], protects against oxidative stress, inflammation [115] and mitochondrial membrane depolarization, and has an insulin-sensitizing effect on adipocytes in female rats [116]; Amitriptyline also increases antioxidant capacity and reduces markers of oxidative stress [117] and Valproate preserves mitochondrial function in a rat model of migraine [118] and increases mitochondrial biogenesis [119].

KBs have been shown to enhance mitochondrial function [120-122] p. 20, [123] and stimulate mitochondrial biogenesis in the rat $[65,124,125]$. Furthermore, D-BHB may bypass complex I deficits due to its effects on complex II (succinate dehydrogenase) [123], thereby maintaining mitochondrial respiration and ATP production even in the presence of a complex I inhibitor (rotenone), but not a complex II inhibitor (malonate) [126].

\subsection{Oxidative Stress}

While reactive oxygen species (ROS) and reactive nitrogen species (RNS) are necessary for certain signalling pathways, their unregulated production is deleterious, if it exceeds the anti-oxidant capacity 
of the organism. All common migraine triggers (stress/relaxation thereafter, fasting/skipping a meal, sleep changes (too much or too little), hormonal changes (including menses or oral contraceptives), weather changes (including hypoxia and high altitude), physical exercise (including sexual activity), alcohol, strong odours (especially perfume or cigarette smoke), intense light (especially bright or blue light) and loud noises $[42,43,127])$ are likely to negatively impact the balancing of oxidative stress levels, either directly or indirectly via negatively impacting mitochondrial functioning or energy metabolism $[9,128]$.

Free iron is highly pro-oxidant and accumulates in the brain stem nuclei of migraine patients proportionally to disease duration [129]. Other heavy metals with pro-oxidant properties may also be increased in migraine [130]. Increased oxidative/nitrosative stress and/or decreased anti-oxidant capacity have also directly been found in migraine patients [117,131-143]. Of all biomarkers examined, superoxide dismutase (SOD) activity seems to be consistently reduced in migraine patients, also interictally [144]. Reduced anti-oxidant capacity or increased oxidative stress in migraine could be related to a genetic predisposition. A polymorphism in the SOD2 gene was associated with unilateral cranial autonomic symptoms in migraine with aura patients [145], and in paediatric migraine patients' polymorphisms in the SOD2 and catalase gene were significantly higher in both migraine with and without aura patients compared to controls [146].

Further support for the role of oxidative stress in migraine is that as aforementioned antioxidants, such as Coenzyme Q10 (400 mg capsules or $300 \mathrm{mg}$ liquid suspension) [101-106] and alpha-lipoic acid (or thioctic acid) [107-109] have been shown to have migraine protective effects.

The elevation of KBs, D-BHB in particular, seems to be an effective method for combating the negative consequences of elevated ROS/RNS. Systemic administration of D-BHB has been shown to reduce $R O S$ production in distinct cortical areas and subregions of the hippocampus and efficiently prevented neuronal death in the cortex of hypoglycemic animals [60]. KBs themselves (AcAc, D-BHB and the non-physiological isomer L-BHB) have scavenging capacity [147].

Hydroxyl radicals $\left({ }^{*} \mathrm{OH}\right)$ were effectively scavenged by D- and L-BHB, but only the administration of D- or L-BHB, but not of AcAc, was able to prevent the hypoglycemia-induced increase in lipid peroxidation in the rat hippocampus [147]. Furthermore, the metabolism of KBs results in a more negative redox potential of the NADP antioxidant system, which is a terminal destructor of ROS [148]. By increasing NADH oxidation, KBs have also been shown to be able to inhibit mitochondrial production of ROS following glutamate excitotoxicity [149].

D-BHB is a natural inhibitor of class $1,2 \mathrm{a}, 3$ and 4 histone deacetylases that repress transcription of the FOXO3a gene; this epigenetic action results in transcription of the enzymes of the antioxidant pathways, such as mitochondrial superoxide dismutase (MnSOD), catalase and metallothionein [150-154]. This has been shown to lead to significantly reduced markers of oxidative stress, such as lipid peroxidation and protein carbonylation, in the kidneys of D-BHB-treated compared to control mice [153]. BHB was also shown to increase FOXO3a activity through direct AMPK phosphorylation [155]. Furthermore, up-regulated glutathione and lipoic acid biosynthesis, enhanced mitochondrial antioxidant status, and protection of mtDNA from oxidant-induced damage in rats fed a KD for 3 weeks compared to controls have also been demonstrated [156]. One possible mechanism by which glutathione biosynthesis may be increased is through the activation of the Nrf2 transcription factor pathway [121]. Hence, KBs may increase antioxidant capacity via several mechanism [121,150].

To summarise, KBs, D-BHB in particular, generate lower levels of oxidative stress and increase antioxidant protein levels in combination with a higher cellular energy output $[16,121,150]$. D-BHB has previously been shown to be elevated as a compensatory response against oxidative stress in failing mice hearts [152]. It can be hypothesized that the aforementioned increased KB levels during a migraine attack $[68,69]$ could represent an analogous reaction in response to increased oxidative stress. 


\subsection{Cerebral Excitability}

The KD is known to be effective as treatment for refractory epilepsy [157]. There is comorbidity and shared genetic susceptibility between migraine and epilepsy [158] and hence partially similar pathophysiologic mechanisms are not unlikely. This assumption is supported by the overlap in certain pharmacological agents used to treat both disorders. One of the most reproducible and ubiquitous interictal abnormalities of the migraineurs' brain is a lack of habituation in neuronal information processing [159]. While the exact underlying mechanisms of this phenomenon are uncertain, an imbalance between neuronal activation and inhibition is likely to be a pathogenic cornerstone in migraine, as it is in epilepsy [160-164]. The genetic association between migraine and epilepsy is illustrated by their co-occurrence in the hitherto known three subtypes of familial hemiplegic migraine (FHM), a rare autosomal dominant monogenic form of migraine. The three mutated genes are responsible for increased glutamate release (FHM1-CACNA1A) [165,166], reduced glutamate re-uptake (FHM2-ATP1A2) [167] or a decreased excitation of inhibitory interneurons (FHM3-SCN1A) [168]. In the common forms of migraine with and without aura, GWAS have identified 38 susceptibility loci [169-171]. These loci point towards genes involved in a variety of functions including glutamate release and re-uptake, and generation of action potentials [172], which may lead to a "generalized" neuronal hyperexcitability of the migraine brain.

The observation that increased KB metabolism produces seizure protection suggests that fuel utilization and neuronal excitability are linked, however, the mechanisms underlying this link are poorly understood [173]. In addition to providing an alternative and more effective energy substrate, its positive effect on oxidative stress levels and mitochondrial functioning, some additional mechanisms have been proposed to underlie the effects of ketosis on cerebral excitability:

A higher synthesis of the inhibitory neurotransmitter GABA from glutamate [174] and a reduction of neuronal firing in GABAergic neurons of the substantia nigra pars reticulata have been demonstrated in response to KBs; this reduction being greater in faster-firing neurons [175]. Another effect of KBs on neural excitability seems to be mediated by an inhibition of glutamate transport and reduction in glutamate release [176], which in turn affects excitatory synaptic transmission [176]. Further reduction in excitability might be achieved via adenosine signalling through A1 purinergic receptors [177] and regulation of excitability by the activity of lactate dehydrogenase [178]. D-BHB has also been shown to be an agonist at FFA receptor GPR41, directly modulating the activity of $\mathrm{N}$-type $\mathrm{Ca}^{2+}$ channels [179]. Furthermore, a KD was shown to activate inward rectifying potassium channels (metabolically sensitive K(ATP) channels) that in turn stabilize central neural excitability $[38,175,180,181]$. D-BHB specifically can bind to BAD (BCL-2 agonist of cell death) that, in addition to being pro-apoptotic, disrupts glucose metabolism KBs and hence opens K(ATP) channels [181]. An increase in inhibition as well as a reduction in excitability could be migraine protective.

\subsection{Cortical Spreading Depression}

Cortical spreading depression (CSD) denotes a wave of cellular depolarization of the neurons and neuroglia within the cerebral cortex and has been implicated as the underlying pathophysiological mechanism in migraine aura. CSD susceptibility is strongly modulated by metabolic factors. Hypoxia can trigger a CSD $[182,183]$ and cerebral glucose availability modulates extrinsically induced CSD in both directions $[184,185]$. Hypoglycaemia significantly prolongs CSD duration and hyperglycaemia protects the tissue from CSD induction [184]. Supplying the rat brain with an alternative energy substrate to glucose via both short- and long-term treatment with a middle chain triglyceride enriched ketogenic diet has a similar protective effect against CSD [21].

\subsection{Inflammation}

Inflammation is a localised response designed to protect tissues against disease, infection or injury. Even though the involvement of neurogenic inflammation in migraine remains controversial [186], 
and migraine has not classically been considered an inflammatory disease, possibly because it is not obviously associated with redness, heat and swelling, several lines of evidence point towards the involvement of pro-inflammatory peptides or a "sterile neurogenic inflammation" in migraine pain (review [187,188]). Most importantly, calcitonin gene related peptide (CGRP) [189-193] see review [194], but also substance $\mathrm{P}$, vasoactive intestinal peptide (VIP), pituitary adenylate cyclase-activating polypeptide (PACAP), nitric oxide (NO) [135,195-198] and to some extent cytokines [199], are all molecules associated with migraine both in animal and human studies review [187,200]. Cytokine Polymorphism (TNF- $\alpha$ and IL-1 $\beta$ gene polymorphisms) in patients with migraine without aura provide some more suggestive evidence for a possible contribution of inflammation in migraine [201]. Meningeal mast cell activation has been discussed to play a role in meningeal nociceptor activation in migraine [202].

D-BHB was reported to reduce inflammation generated by macrophages via a mechanism independent from any of those reported above [203]. The NLR family, pyrin domain-containing 3 (NLRP3) inflammasome, which is expressed mainly in immune cells, is activated by a shift to low cytoplasmic K+ levels [204]. Youm et al. noted that D-BHB prevented the decline in $\mathrm{K}+$ levels and prevented activation of NLRP3 [203]. A reduction in pain and inflammation has been observed in rats fed the KD [205-207], which could further be migraine protective.

\subsection{Gut Microbiome}

The potential role of the microbiome in migraine pathophysiology is not yet fully established. Two recent reviews report an increased frequency of gastrointestinal (GI) symptoms or disorders in migraine patients compared to the general population, such as increased rates of nausea, cyclic vomiting syndrome, inflammatory bowel syndrome, irritable bowel syndrome, celiac disease, gastroparesis, hepatobiliary disorders, helicobacter pylori infection, gastric stasis, and alterations in the microbiota [208-210]. While there was no evidence for an added benefit of probiotics in an RCT with 63 episodic migraineurs [211] an uncontrolled observational study with 1020 patients using a multispecies probiotic showed a significant reduction in migraine days, headache intensity and the use of painkillers [212]. Additionally, an immunoglobulin-G based elimination diet among migraine patients with irritable bowel syndrome was associated with significant reductions in attack frequency, duration, severity and medication use [213]. Possible underlying mechanisms of migraine and GI diseases could be inflammation, alterations in the gut microbiota and its metabolites (such as neurotransmitters and neuropeptides) as well as increased gut permeability.

The role of inflammation in migraine as well as the anti-inflammatory effects of ketosis have already been reviewed above. In addition, it has very recently been shown that a KD in children with severe epilepsy alters the gut microbiome [214,215]. Recent experiments in mice suggest that the KD seems to mediate some of its anti-seizure effects [216]. Mice treated with antibiotics or reared germ free were resistant to KD-mediated seizure protection otherwise found. Enrichment of and co-colonization with the KD-associated Akkermansia and Parabacteroides was shown to restore seizure protection. Even in mice fed a control diet, transplantation of the KD gut microbiota and treatment with Akkermansia and Parabacteroides each conferred seizure protection [216].

In support of this, in infants with refractory epilepsy a KD decreased seizure frequency in the majority of cases and significantly changed the gut microbial composition towards that of healthy controls: Bacteroides and Prevotella increased, while Cronobacter levels decreased by approximately $50 \%$ [217]. Other studies show a normalization of the microbiota in two other neurological disorders, namely autism [218] and multiple sclerosis [219]. In the BTBRT $+\mathrm{tf} / \mathrm{j}$ mouse model of autism spectrum disorder, a KD significantly increased the Firmicutes/Bacteroidetes ratio which is typically low in autism spectrum disorder and also normalized the overabundance of the mucin-degrading bacterium Akkermansia muciniphila [218]. In patients with multiple sclerosis who were characterized by a reduced mass and diversity of microbial species, a KD initially decreased total gut bacterial concentrations 
during the first weeks, but, when maintained over six months, was able to restore the microbial mass to levels similar as in healthy controls [219].

However, these findings could not be replicated in all studies. For example, a small study on children with severe epilepsy found that the relative abundance of bifidobacteria as well as E. rectale and Dialister was significantly diminished during the KD intervention while an increase in relative abundance of E. coli was observed instead [214]. In a small study on GLUT1 deficiency syndrome a significant increase in Desulfovibrio spp., a bacterial group supposed to be involved in the exacerbation of the inflammatory condition of the gut mucosa, was found [220]. The differences observed might be due to the kind of KD employed, as different forms of the KD can vary tremendously in microand even macronutrient content, depending on the ratio of fat to protein/carbs, the use of processed meal replacements or processed vegetable oils, source of protein and carbohydrates and other factors. The children with severe epilepsy were mostly on a very strict classical KD with 4:1 ratio that allows for little fibre content. In addition, the use of pro-inflammatory processed vegetable oils and instant ketogenic formulas or meal replacements may be suboptimal for the gut microbiome. Lastly, given the structural and functional similarity between butyrate and $\mathrm{BHB}$, it could be hypothesized that higher systemic concentrations of the latter in case of the higher KD rations (4:1) could decrease the importance of microbial butyrate production [221].

In sum, an alteration of the microbiome and its downstream beneficial effects on gut permeability, synthesis of metabolites and neuropeptides, as well as inflammation could thus be another potential disease modifying mechanism of ketosis in migraine.

\section{Discussion and Conclusions}

Migraine is a very heterogeneous disease, with most probably a multitude of fairly common genetic polymorphisms and in turn pathophysiological mechanisms contributing to the migraine phenotype. We have reviewed the potential contribution of eight such pathophysiological mechanisms and their possible exploitation through dietary ketosis (KDs and/or D-BHB supplementation): (1) hypoglycaemia/hypometabolism, (2) glucose transport, (3) mitochondrial functioning, (4) oxidative stress, (5) cerebral Excitability, (6) CSD, (7) inflammation and (8) the microbiome. Which mechanisms contribute to the migraine phenotype in a given individual are likely to vary. Further research is needed to confirm these mechanistic hypotheses and their translational relevance for patients. Furthermore, the scope and importance of these metabolic mechanisms within the broad range of migraine pathophysiology remains to be determined.

With migraine being such a diverse and multigenic disease, finding the one treatment target seems a nearly impossible endeavour. Exciting recent technological advances in the field of genetics and induced pluripotent stem cells are paving the way for future more personalised treatment approaches. Until those reach the clinic, an elevation of KBs, D-BHB in particular, which have been shown to potentially influence all of the aforementioned migraine pathophysiological mechanisms, might offer a long-needed relatively side-effect free remedy for at least a proportion of migraine sufferers.

It remains to be determined whether the absence/restriction of dietary carbohydrates, the presence of KBs, or both, are of primary importance for the potentially migraine protective effects of the KD that has previously been demonstrated. Additionally, third factors, such as increased fatty acids, amino acids, supplementation with medium-chain triglycerides [222] or other dietary changes as well as alteration of the microbiome could also be disease modifying. The potential preventative anti-migraine effect of supplementation with BHB without a strict dietary change is currently being examined in an RCT [223] and could help answer some of these questions.

Moreover, a lot of the mechanistic effects of ketosis and/or presence of BHB have been examined in animals and more clinical research is needed to validate those effects. Such future clinical research could additionally help determine whether, and to what extent all the aforementioned potentially disease-modifying effects of ketosis are actually also occurring in migraine patients. 
Patents: E.C.G. and D.F. are the inventors of the patent WO 2018/115158 Al) held by the UKBB and University of Basel on the use of beta-hydroxybutyrate in migraine prevention. D.P.D. is inventor on International Patent \# PCT/US2014/031237, University of South Florida, “Compositions and Methods for Producing Elevated and Sustained Ketosis". D.P.D. is co-owners of the company Ketone Technologies LLC. These interests have been reviewed and managed by the University in accordance with its Institutional and Individual Conflict of Interest policies.

Author Contributions: E.C.G. was responsible for literature search and the main composition of the manuscript, including display items. R.J.K. and J.S. edited the manuscript and provided additional text and citations. D.P.D and D.F. edited the manuscript. All authors proofread the final manuscript prior to submission.

Funding: This review article received no external funding.

Conflicts of Interest: E.C.G. is the founder of KetoSwiss AG and E.C.G. and D.F. are the inventors of the patent WO 2018/115158 Al) held by the UKBB and University of Basel. D.P.D. is inventor on International Patent \# PCT/US2014/031237, University of South Florida, "Compositions and Methods for Producing Elevated and Sustained Ketosis". D.P.D. is co-owners of the company Ketone Technologies LLC. These interests have been reviewed and managed by the University in accordance with its Institutional and Individual Conflict of Interest policies. R.J.K. and J.S. have no conflicts of interest for this publication.

\section{References}

1. Stovner, L.J.; Hoff, J.M.; Svalheim, S.; Gilhus, N.E. Neurological disorders in the Global Burden of Disease 2010 study. Acta Neurol. Scand. 2014, 129, 1-6. [CrossRef] [PubMed]

2. Stovner, L.J.; Hagen, K. Prevalence, burden, and cost of headache disorders. Curr. Opin. Neurol. 2006, 19, 281-285. [CrossRef] [PubMed]

3. Olesen, J.; Gustavsson, A.; Svensson, M.; Wittchen, H.-U.; Jönsson, B. The economic cost of brain disorders in Europe. Eur. J. Neurol. 2012, 19, 155-162. [CrossRef] [PubMed]

4. Buse, D.C.; Lipton, R.B. Global perspectives on the burden of episodic and chronic migraine. Cephalalgia Int. J. Headache 2013, 33, 885-890. [CrossRef] [PubMed]

5. Sprenger, T.; Goadsby, P.J. Migraine pathogenesis and state of pharmacological treatment options. BMC Med. 2009, 7, 71. [CrossRef]

6. Leonardi, M. Burden of migraine: What should we say more? Neurol. Sci. 2015, 36 (Suppl. 1), 1-3. [CrossRef]

7. Lipton, R.B.; Buse, D.C.; Serrano, D.; Holland, S.; Reed, M.L. Examination of unmet treatment needs among persons with episodic migraine: Results of the American Migraine Prevalence and Prevention (AMPP) Study. Headache 2013, 53, 1300-1311. [CrossRef] [PubMed]

8. Pietrobon, D.; Moskowitz, M.A. Pathophysiology of migraine. Annu. Rev. Physiol. 2013, 75, 365-391. [CrossRef]

9. Gross, E.C.; Lisicki, M.; Fischer, D.; Sandor, P.S.; Schoenen, J. The metabilic face of migraine. Nat. Neurosci. 2019, 7, 50708-50718.

10. Edmond, J.; Robbins, R.A.; Bergstrom, J.D.; Cole, R.A.; de Vellis, J. Capacity for substrate utilization in oxidative metabolism by neurons, astrocytes, and oligodendrocytes from developing brain in primary culture. J. Neurosci. Res. 1987, 18, 551-561. [CrossRef]

11. Bailey, E.E.; Pfeifer, H.H.; Thiele, E.A. The use of diet in the treatment of epilepsy. Epilepsy Behav. EEB 2005, $6,4-8$.

12. Danial, N.N.; Hartman, A.L.; Stafstrom, C.E.; Thio, L.L. How does the ketogenic diet work? Four potential mechanisms. J. Child Neurol. 2013, 28, 1027-1033. [CrossRef]

13. Stafstrom, C.E.; Rho, J.M. The ketogenic diet as a treatment paradigm for diverse neurological disorders. Front. Pharmacol. 2012, 3, 59. [CrossRef]

14. Barañano, K.W.; Hartman, A.L. The ketogenic diet: Uses in epilepsy and other neurologic illnesses. Curr. Treat. Opt. Neurol. 2008, 10, 410-419. [CrossRef]

15. Dedkova, E.N.; Blatter, L.A. Role of $\beta$-hydroxybutyrate, its polymer poly- $\beta$-hydroxybutyrate and inorganic polyphosphate in mammalian health and disease. Front. Physiol. 2014, 5, 260. [CrossRef]

16. Puchalska, P.; Crawford, P.A. Multi-dimensional Roles of Ketone Bodies in Fuel Metabolism, Signaling, and Therapeutics. Cell Metab. 2017, 25, 262-284. [CrossRef]

17. Veech, R.L. The therapeutic implications of ketone bodies: The effects of ketone bodies in pathological conditions: Ketosis, ketogenic diet, redox states, insulin resistance, and mitochondrial metabolism. Prostaglandins Leukot. Essential Fatty Acids 2004, 70, 309-319. [CrossRef] 
18. Owen, O.E.; Felig, P.; Morgan, A.P.; Wahren, J.; Cahill, G.F. Liver and kidney metabolism during prolonged starvation. J. Clin. Investig. 1969, 48, 574-583. [CrossRef]

19. Nei, M.; Ngo, L.; Sirven, J.I.; Sperling, M.R. Ketogenic diet in adolescents and adults with epilepsy. Seizure 2014, 23, 439-442. [CrossRef]

20. Reid, C.A.; Mullen, S.; Kim, T.H.; Petrou, S. Epilepsy, energy deficiency and new therapeutic approaches including diet. Pharmacol. Ther. 2014, 144, 192-201. [CrossRef]

21. De Almeida Rabello Oliveira, M.; da Rocha Ataíde, T.; de Oliveira, S.L.; de Melo Lucena, A.L.; de Lira, C.E.P.R.; Soares, A.A.; De Almeida, C.B.S.; Ximenes-da-Silva, A. Effects of short-term and long-term treatment with medium- and long-chain triglycerides ketogenic diet on cortical spreading depression in young rats. Neurosci. Lett. 2008, 434, 66-70. [CrossRef] [PubMed]

22. SCHNABEL, T.G. An Experience with a Ketogenic Dietary in Migraine. Ann. Intern. Med. 1928, $2,341$.

23. Henderson, S.T.; Vogel, J.L.; Barr, L.J.; Garvin, F.; Jones, J.J.; Costantini, L.C. Study of the ketogenic agent AC-1202 in mild to moderate Alzheimer's disease: A randomized, double-blind, placebo-controlled, multicenter trial. Nutr. Metab. 2009, 6, 31. [CrossRef] [PubMed]

24. Klepper, J.; Leiendecker, B.; Riemann, E.; Baumeister, F.A. [The ketogenic diet in German-speaking countries: Update 2003]. Klin. Pädiatrie 2004, 216, 277-285. [CrossRef] [PubMed]

25. Paoli, A.; Bianco, A.; Damiani, E.; Bosco, G. Ketogenic diet in neuromuscular and neurodegenerative diseases. BioMed Res. Int. 2014, 2014, 474296. [CrossRef] [PubMed]

26. Freeman, J.M.; Kossoff, E.H. Ketosis and the ketogenic diet, 2010: Advances in treating epilepsy and other disorders. Adv. Pediatrics 2010, 57, 315-329. [CrossRef] [PubMed]

27. Liu, Y.C.; Wang, H.-S. Medium-chain triglyceride ketogenic diet, an effective treatment for drug-resistant epilepsy and a comparison with other ketogenic diets. Biomed. J. 2013, 36, 9-15. [CrossRef]

28. Valayannopoulos, V.; Bajolle, F.; Arnoux, J.-B.; Dubois, S.; Sannier, N.; Baussan, C.; Petit, F.; Labrune, P.; Rabier, D.; Ottolenghi, C.; et al. Successful treatment of severe cardiomyopathy in glycogen storage disease type III With D,L-3-hydroxybutyrate, ketogenic and high-protein diet. Pediatric Res. 2011, 70, 638-641. [CrossRef]

29. Clarke, K.; Tchabanenko, K.; Pawlosky, R.; Carter, E.; Todd King, M.; Musa-Veloso, K.; Ho, M.; Roberts, A.; Robertson, J.; Vanitallie, T.B.; et al. Kinetics, safety and tolerability of (R)-3-hydroxybutyl (R)-3-hydroxybutyrate in healthy adult subjects. Regul. Toxicol. Pharmacol. 2012, 63, 401-408. [CrossRef] [PubMed]

30. Kossoff, E.H.; Cervenka, M.C.; Henry, B.J.; Haney, C.A.; Turner, Z. A decade of the modified Atkins diet (2003-2013): Results, insights, and future directions. Epilepsy Behav. EEB 2013, 29, 437-442.

31. Newport, M.T.; VanItallie, T.B.; Kashiwaya, Y.; King, M.T.; Veech, R.L. A new way to produce hyperketonemia: Use of ketone ester in a case of Alzheimer's disease. Alzheimer's Dement. J. Alzheimer's Assoc. 2015, 11, 99-103. [CrossRef]

32. Douris, N.; Melman, T.; Pecherer, J.M.; Pissios, P.; Flier, J.S.; Cantley, L.C.; Locasale, J.W.; Maratos-Flier, E. Adaptive changes in amino acid metabolism permit normal longevity in mice consuming a low-carbohydrate ketogenic diet. Biochim. Biophys. Acta 2015, 1852, 2056-2065. [CrossRef] [PubMed]

33. Strahlman, R.S. Can ketosis help migraine sufferers? A case report. Headache 2006, 46, 182. [CrossRef] [PubMed]

34. Di Lorenzo, C.; Currà, A.; Sirianni, G.; Coppola, G.; Bracaglia, M.; Cardillo, A.; De Nardis, L.; Pierelli, F. Diet transiently improves migraine in two twin sisters: Possible role of ketogenesis? Funct. Neurol. 2013, 28, 305-308.

35. Maggioni, F.; Margoni, M.; Zanchin, G. Ketogenic diet in migraine treatment: A brief but ancient history. Cephalalgia Int. J. Headache 2011, 31, 1150-1151. [CrossRef] [PubMed]

36. Di Lorenzo, C.; Coppola, G.; Bracaglia, M.; Di Lenola, D.; Evangelista, M.; Sirianni, G.; Rossi, P.; Di Lorenzo, G.; Serrao, M.; Parisi, V.; et al. Cortical functional correlates of responsiveness to short-lasting preventive intervention with ketogenic diet in migraine: A multimodal evoked potentials study. J. Headache Pain 2016, 17, 58. [CrossRef] [PubMed]

37. Di Lorenzo, C.; Coppola, G.; Sirianni, G.; Di Lorenzo, G.; Bracaglia, M.; Di Lenola, D.; Siracusano, A.; Rossi, P.; Pierelli, F. Migraine improvement during short lasting ketogenesis: A proof-of-concept study. Eur. J. Neurol. 2015, 22, 170-177. [CrossRef] 
38. Lutas, A.; Yellen, G. The ketogenic diet: Metabolic influences on brain excitability and epilepsy. Trends Neurosci. 2013, 36, 32-40. [CrossRef]

39. Blau, J.N.; Cumings, J.N. Method of precipitating and preventing some migraine attacks. Br. Med. J. 1966, 2, 1242-1243. [CrossRef]

40. Gray, P.A.; Burtness, H.I. HYPOGLYCEMIC HEADACHE*. Endocrinology 1935, 19, 549-560. [CrossRef]

41. Roberts, H.J. Migraine and related vascular headaches due to diabetogenic hyperinsulinism. Observations on pathogenesis and rational treatment in 421 patients. Headache 1967, 7, 41-62. [CrossRef]

42. Pavlovic, J.M.; Buse, D.C.; Sollars, C.M.; Haut, S.; Lipton, R.B. Trigger Factors and Premonitory Features of Migraine Attacks: Summary of Studies. Headache J. Head Face Pain 2014, 54, 1670-1679. [CrossRef]

43. Peroutka, S.J. What turns on a migraine? A systematic review of migraine precipitating factors. Curr. Pain Headache Rep. 2014, 18, 454. [CrossRef]

44. Yadav, R.K.; Kalita, J.; Misra, U.K. A Study of Triggers of Migraine in India. Pain Med. 2010, 11, 44-47. [CrossRef]

45. Binder, C.; Bendtson, I. Endocrine emergencies. Hypoglycaemia. Bailliere's Clinical Endocrinol. Metab. 1992, 6, 23-39. [CrossRef]

46. Abu-Salameh, I.; Plakht, Y.; Ifergane, G. Migraine exacerbation during Ramadan fasting. J. Headache Pain 2010, 11, 513-517. [CrossRef]

47. Haghighi, F.S.; Rahmanian, M.; Namiranian, N.; Arzaghi, S.M.; Dehghan, F.; Chavoshzade, F.; Sepehri, F. Migraine and type 2 diabetes; is there any association? J. Diabetes Metab. Disord. 2015, 15, 37. [CrossRef]

48. Welch, K.M.; Levine, S.R.; D'Andrea, G.; Schultz, L.R.; Helpern, J.A. Preliminary observations on brain energy metabolism in migraine studied by in vivo phosphorus 31 NMR spectroscopy. Neurology 1989, 39, 538-541. [CrossRef]

49. Barbiroli, B.; Montagna, P.; Cortelli, P.; Funicello, R.; Iotti, S.; Monari, L.; Pierangeli, G.; Zaniol, P.; Lugaresi, E. Abnormal brain and muscle energy metabolism shown by 31P magnetic resonance spectroscopy in patients affected by migraine with aura. Neurology 1992, 42, 1209-1214. [CrossRef]

50. Kim, J.H.; Kim, S.; Suh, S.I.; Koh, S.B.; Park, K.W.; Oh, K. Interictal metabolic changes in episodic migraine: A voxel-based FDG-PET study. Cephalalgia 2010, 30, 53-61. [CrossRef]

51. Lodi, R.; Montagna, P.; Soriani, S.; Iotti, S.; Arnaldi, C.; Cortelli, P.; Pierangeli, G.; Patuelli, A.; Zaniol, P.; Barbiroli, B. Deficit of Brain and Skeletal Muscle Bioenergetics and Low Brain Magnesium in Juvenile Migraine: An in Vivo ${ }^{31}$ P Magnetic Resonance Spectroscopy Interictal Study. Pediatric Res. 1997, 42, 866-871. [CrossRef]

52. Lodi, R.; Iotti, S.; Cortelli, P.; Pierangeli, G.; Cevoli, S.; Clementi, V.; Soriani, S.; Montagna, P.; Barbiroli, B. Deficient energy metabolism is associated with low free magnesium in the brains of patients with migraine and cluster headache. Brain Res. Bull. 2001, 54, 437-441. [CrossRef]

53. Montagna, P.; Cortelli, P.; Monari, L.; Pierangeli, G.; Parchi, P.; Lodi, R.; Iotti, S.; Frassineti, C.; Zaniol, P.; Lugaresi, E. 31P-magnetic resonance spectroscopy in migraine without aura. Neurology 1994, 44, 666-669. [CrossRef]

54. Reyngoudt, H.; Achten, E.; Paemeleire, K. Magnetic resonance spectroscopy in migraine: What have we learned so far? Cephalalgia Int. J. Headache 2012, 32, 845-859. [CrossRef]

55. Schulz, U.G.; Blamire, A.M.; Corkill, R.G.; Davies, P.; Styles, P.; Rothwell, P.M. Association between cortical metabolite levels and clinical manifestations of migrainous aura: An MR-spectroscopy study. Brain 2007, 130, 3102-3110. [CrossRef]

56. Lodi, R.; Kemp, G.J.; Pierangeli, G.; Cortelli, P.; Iotti, S.; Radda, G.K.; Barbiroli, B. Quantitative analysis of skeletal muscle bioenergetics and proton efflux in migraine and cluster headache. J. Neurol. Sci. 1997, 146, 73-80. [CrossRef]

57. Barbiroli, B.; Montagna, P.; Cortelli, P.; Martinelli, P.; Sacquegna, T.; Zaniol, P.; Lugaresi, E. Complicated migraine studied by phosphorus magnetic resonance spectroscopy. Cephalalgia 1990, 10, 263-272. [CrossRef]

58. Reyngoudt, H.; Paemeleire, K.; Descamps, B.; De Deene, Y.; Achten, E. 31P-MRS demonstrates a reduction in high-energy phosphates in the occipital lobe of migraine without aura patients. Cephalalgia Int. J. Headache 2011, 31, 1243-1253. [CrossRef] 
59. Lisicki, M.; D’Ostilio, K.; Coppola, G.; Scholtes, F.; Maertens de Noordhout, A.; Parisi, V.; Schoenen, J.; Magis, D. Evidence of an increased neuronal activation-to-resting glucose uptake ratio in the visual cortex of migraine patients: A study comparing 18FDG-PET and visual evoked potentials. J. Headache Pain 2018, 19, 49. [CrossRef]

60. Julio-Amilpas, A.; Montiel, T.; Soto-Tinoco, E.; Gerónimo-Olvera, C.; Massieu, L. Protection of hypoglycemia-induced neuronal death by $\beta$-hydroxybutyrate involves the preservation of energy levels and decreased production of reactive oxygen species. J. Cereb. Blood Flow Metab. 2015, 35, 851-860. [CrossRef]

61. Courchesne-Loyer, A.; Croteau, E.; Castellano, C.-A.; St-Pierre, V.; Hennebelle, M.; Cunnane, S.C. Inverse relationship between brain glucose and ketone metabolism in adults during short-term moderate dietary ketosis: A dual tracer quantitative positron emission tomography study. J. Cereb. Blood Flow Metab. 2017, 37, 2485-2493. [CrossRef]

62. Zhang, Y.; Kuang, Y.; Xu, K.; Harris, D.; Lee, Z.; LaManna, J.; Puchowicz, M.A. Ketosis proportionately spares glucose utilization in brain. J. Cereb. Blood Flow Metab. 2013, 33, 1307-1311. [CrossRef]

63. Chowdhury, G.M.I.; Jiang, L.; Rothman, D.L.; Behar, K.L. The contribution of ketone bodies to basal and activity-dependent neuronal oxidation in vivo. J. Cereb. Blood Flow Metab. 2014, 34, 1233-1242. [CrossRef]

64. Sato, K.; Kashiwaya, Y.; Keon, C.A.; Tsuchiya, N.; King, M.T.; Radda, G.K.; Chance, B.; Clarke, K.; Veech, R.L. Insulin, ketone bodies, and mitochondrial energy transduction. FASEB J. 1995, 9, 651-658. [CrossRef]

65. Bough, K.J.; Wetherington, J.; Hassel, B.; Pare, J.F.; Gawryluk, J.W.; Greene, J.G.; Shaw, R.; Smith, Y.; Geiger, J.D.; Dingledine, R.J. Mitochondrial biogenesis in the anticonvulsant mechanism of the ketogenic diet. Ann. Neurol. 2006, 60, 223-235. [CrossRef]

66. DeVivo, D.C.; Leckie, M.P.; Ferrendelli, J.S.; McDougal, D.B. Chronic ketosis and cerebral metabolism. Ann. Neurol. 1978, 3, 331-337. [CrossRef]

67. Pan, J.W.; Bebin, E.M.; Chu, W.J.; Hetherington, H.P. Ketosis and epilepsy: 31P spectroscopic imaging at 4.1 T. Epilepsia 1999, 40, 703-707. [CrossRef]

68. Hockaday, J.; Williamson, D.H.; Whitty, C.W.M. Blood-glucose levels and fatty-acid metabolism in migraine related to fasting. Lancet 1971, 297, 1153-1156. [CrossRef]

69. Shaw, S.W.; Johnson, R.H.; Keogh, H.J. Metabolic changes during glucose tolerance tests in migraine attacks. J. Neurol. Sci. 1977, 33, 51-59. [CrossRef]

70. Mohammad, S.S.; Coman, D.; Calvert, S. Glucose transporter 1 deficiency syndrome and hemiplegic migraines as a dominant presenting clinical feature. J. Paediatr. Child Health 2014, 50, 1025-1026.

71. Uemura, E.; Greenlee, H.W. Insulin regulates neuronal glucose uptake by promoting translocation of glucose transporter GLUT3. Exp. Neurol. 2006, 198, 48-53. [CrossRef]

72. Dexter, J.D.; Roberts, J.; Byer, J.A. The Five Hour Glucose Tolerance Test and Effect of Low Sucrose Diet in Migraine. Headache J. Head Face Pain 1978, 18, 91-94. [CrossRef]

73. Wang, X.; Li, X.; Diao, Y.; Meng, S.; Xing, Y.; Zhou, H.; Yang, D.; Sun, J.; Chen, H.; Zhao, Y. Are Glucose and Insulin Metabolism and Diabetes Associated with Migraine? A Community-Based, Case-Control Study. J. Oral Facial Pain Headache 2017, 31, 240-250. [CrossRef]

74. Rainero, I.; Limone, P.; Ferrero, M.; Valfrè, W.; Pelissetto, C.; Rubino, E.; Gentile, S.; Lo Giudice, R.; Pinessi, L. Insulin sensitivity is impaired in patients with migraine. Cephalalgia 2005, 25, 593-597. [CrossRef]

75. Fava, A.; Pirritano, D.; Consoli, D.; Plastino, M.; Casalinuovo, F.; Cristofaro, S.; Colica, C.; Ermio, C.; De Bartolo, M.; Opipari, C.; et al. Chronic migraine in women is associated with insulin resistance: A cross-sectional study. Eur. J. Neurol. 2014, 21, 267-272. [CrossRef]

76. Cavestro, C.; Rosatello, A.; Micca, G.; Ravotto, M.; Marino, M.P.; Asteggiano, G.; Beghi, E. Insulin Metabolism is Altered in Migraineurs: A New Pathogenic Mechanism for Migraine? Headache J. Head Face Pain 2007, 47, 1436-1442. [CrossRef]

77. Sacco, S.; Altobelli, E.; Ornello, R.; Ripa, P.; Pistoia, F.; Carolei, A. Insulin resistance in migraineurs: Results from a case-control study. Cephalalgia 2014, 34, 349-356. [CrossRef]

78. Rainero, I.; Govone, F.; Gai, A.; Vacca, A.; Rubino, E. Is Migraine Primarily a Metaboloendocrine Disorder? Curr. Pain Headache Rep. 2018, 22, 36. [CrossRef]

79. Curtain, R.; Tajouri, L.; Lea, R.; MacMillan, J.; Griffiths, L. No mutations detected in the INSR gene in a chromosome 19p13 linked migraine pedigree. Eur. J. Med. Genet. 2006, 49, 57-62. [CrossRef] 
80. Kaunisto, M.A.; Tikka, P.J.; Kallela, M.; Leal, S.M.; Papp, J.C.; Korhonen, A.; Hämäläinen, E.; Harno, H.; Havanka, H.; Nissilä, M.; et al. Chromosome 19p13 loci in Finnish migraine with aura families. Am. J. Med. Genet. B Neuropsychiatr. Genet. 2005, 132B, 85-89. [CrossRef]

81. McCarthy, L.C.; Hosford, D.A.; Riley, J.H.; Bird, M.I.; White, N.J.; Hewett, D.R.; Peroutka, S.J.; Griffiths, L.R.; Boyd, P.R.; Lea, R.A.; et al. Single-nucleotide polymorphism alleles in the insulin receptor gene are associated with typical migraine. Genomics 2001, 78, 135-149. [CrossRef]

82. Netzer, C.; Freudenberg, J.; Heinze, A.; Heinze-Kuhn, K.; Goebel, I.; McCarthy, L.C.; Roses, A.D.; Göbel, H.; Todt, U.; Kubisch, C. Replication study of the insulin receptor gene in migraine with aura. Genomics 2008, 91, 503-507. [CrossRef]

83. Guzmán, M.; Blázquez, C. Ketone body synthesis in the brain: Possible neuroprotective effects. Prostaglandins Leukot. Essent. Fatty Acids 2004, 70, 287-292. [CrossRef] [PubMed]

84. Takahashi, S.; Iizumi, T.; Mashima, K.; Abe, T.; Suzuki, N. Roles and regulation of ketogenesis in cultured astroglia and neurons under hypoxia and hypoglycemia. ASN Neuro 2014, 6, 1759091414550997. [CrossRef] [PubMed]

85. Veggiotti, P.; De Giorgis, V. Dietary Treatments and New Therapeutic Perspective in GLUT1 Deficiency Syndrome. Curr. Treat. Opt. Neurol. 2014, 16, 291. [CrossRef]

86. Valdebenito, R.; Ruminot, I.; Garrido-Gerter, P.; Fernández-Moncada, I.; Forero-Quintero, L.; Alegría, K.; Becker, H.M.; Deitmer, J.W.; Barros, L.F. Targeting of astrocytic glucose metabolism by beta-hydroxybutyrate. J. Cereb. Blood Flow Metab. 2016, 36, 1813-1822. [CrossRef] [PubMed]

87. Kraya, T.; Deschauer, M.; Joshi, P.R.; Zierz, S.; Gaul, C. Prevalence of Headache in Patients With Mitochondrial Disease: A Cross-Sectional Study. Headache 2018, 58, 45-52. [CrossRef]

88. Vollono, C.; Primiano, G.; Della Marca, G.; Losurdo, A.; Servidei, S. Migraine in mitochondrial disorders: Prevalence and characteristics. Cephalalgia 2018, 38, 1093-1106. [CrossRef] [PubMed]

89. Montagna, P.; Gallassi, R.; Medori, R.; Govoni, E.; Zeviani, M.; Di Mauro, S.; Lugaresi, E.; Andermann, F. MELAS syndrome: Characteristic migrainous and epileptic features and maternal transmission. Neurology 1988, 38, 751-754. [CrossRef]

90. Lemos, C.; Alonso, I.; Barros, J.; Sequeiros, J.; Pereira-Monteiro, J.; Mendonça, D.; Sousa, A. Assessing risk factors for migraine: Differences in gender transmission. PLoS ONE 2012, 7, e50626. [CrossRef]

91. Eising, E.; Huisman, S.M.H.; Mahfouz, A.; Vijfhuizen, L.S.; Anttila, V.; Winsvold, B.S.; Kurth, T.; Ikram, M.A.; Freilinger, T.; Kaprio, J.; et al. Gene co-expression analysis identifies brain regions and cell types involved in migraine pathophysiology: A GWAS-based study using the Allen Human Brain Atlas. Hum. Genet. 2016, 135, 425-439. [CrossRef]

92. Littlewood, J.; Glover, V.; Sandler, M.; Peatfield, R.; Petty, R.; Clifford Rose, F. Low platelet monoamine oxidase activity in headache: No correlation with phenolsulphotransferase, succinate dehydrogenase, platelet preparation method or smoking. J. Neurol. Neurosurg. Psychiatry 1984, 47, 338-343. [CrossRef]

93. Sangiorgi, S.; Mochi, M.; Riva, R.; Cortelli, P.; Monari, L.; Pierangeli, G.; Montagna, P. Abnormal platelet mitochondrial function in patients affected by migraine with and without aura. Cephalalgia Int. J. Headache 1994, 14, 21-23. [CrossRef]

94. Van Houten, B.; Hunter, S.E.; Meyer, J.N. Mitochondrial DNA damage induced autophagy, cell death, and disease. Front. Biosci. (Landmark Ed) 2016, 21, 42-54. [CrossRef]

95. Yang, J.-L.; Weissman, L.; Bohr, V.A.; Mattson, M.P. Mitochondrial DNA damage and repair in neurodegenerative disorders. DNA Repair 2008, 7, 1110-1120. [CrossRef]

96. Boehnke, C.; Reuter, U.; Flach, U.; Schuh-Hofer, S.; Einhäupl, K.M.; Arnold, G. High-dose riboflavin treatment is efficacious in migraine prophylaxis: An open study in a tertiary care centre. Eur. J. Neurol. 2004, 11, 475-477. [CrossRef]

97. Condò, M.; Posar, A.; Arbizzani, A.; Parmeggiani, A. Riboflavin prophylaxis in pediatric and adolescent migraine. J. Headache Pain 2009, 10, 361-365. [CrossRef]

98. Gaul, C.; Diener, H.-C.; Danesch, U.; Migravent ${ }^{\circledR}$ Study Group. Improvement of migraine symptoms with a proprietary supplement containing riboflavin, magnesium and Q10: A randomized, placebo-controlled, double-blind, multicenter trial. J. Headache Pain 2015, 16, 516. [CrossRef]

99. Schoenen, J.; Jacquy, J.; Lenaerts, M. Effectiveness of high-dose riboflavin in migraine prophylaxis. A randomized controlled trial. Neurology 1998, 50, 466-470. [CrossRef] 
100. Rahimdel, A.; Mellat, A.; Zeinali, A.; Jafari, E.; Ayatollahi, P. Comparison between Intravenous Sodium Valproate and Subcutaneous Sumatriptan for Treatment of Acute Migraine Attacks; Double-Blind Randomized Clinical Trial. Iran. J. Med. Sci. 2014, 39, 171-177.

101. Dahri, M.; Hashemilar, M.; Asghari-Jafarabadi, M.; Tarighat-Esfanjani, A. Efficacy of coenzyme Q10 for the prevention of migraine in women: A randomized, double-blind, placebo-controlled study. Eur. J. Integr. Med. 2017, 16, 8-14. [CrossRef]

102. Dahri, M.; Tarighat-Esfanjani, A.; Asghari-Jafarabadi, M.; Hashemilar, M. Oral coenzyme Q10 supplementation in patients with migraine: Effects on clinical features and inflammatory markers. Nutr. Neurosci. 2018, 0, 1-9. [CrossRef]

103. Sándor, P.S.; Di Clemente, L.; Coppola, G.; Saenger, U.; Fumal, A.; Magis, D.; Seidel, L.; Agosti, R.M.; Schoenen, J. Efficacy of coenzyme Q10 in migraine prophylaxis: A randomized controlled trial. Neurology 2005, 64, 713-715. [CrossRef]

104. Hajihashemi, P.; Askari, G.; Khorvash, F.; Reza Maracy, M.; Nourian, M. The effects of concurrent Coenzyme Q10, L-carnitine supplementation in migraine prophylaxis: A randomized, placebo-controlled, double-blind trial. Cephalalgia 2019, 6, 0333102418821661. [CrossRef]

105. Shoeibi, A.; Olfati, N.; Soltani Sabi, M.; Salehi, M.; Mali, S.; Akbari Oryani, M. Effectiveness of coenzyme Q10 in prophylactic treatment of migraine headache: An open-label, add-on, controlled trial. Acta Neurol. Belg. 2017, 117, 103-109. [CrossRef]

106. Rozen, T.; Oshinsky, M.; Gebeline, C.; Bradley, K.; Young, W.; Shechter, A.; Silberstein, S. Open label trial of coenzyme Q10 as a migraine preventive. Cephalalgia 2002, 22, 137-141. [CrossRef]

107. Magis, D.; Ambrosini, A.; Sándor, P.; Jacquy, J.; Laloux, P.; Schoenen, J. A randomized double-blind placebo-controlled trial of thioctic acid in migraine prophylaxis. Headache 2007, 47, 52-57. [CrossRef]

108. Cavestro, C.; Bedogni, G.; Molinari, F.; Mandrino, S.; Rota, E.; Frigeri, M.C. Alpha-Lipoic Acid Shows Promise to Improve Migraine in Patients with Insulin Resistance: A 6-Month Exploratory Study. J. Med. Food 2018, 21, 269-273. [CrossRef]

109. Ali, A.M.; Awad, T.G.; Al-Adl, N.M. Efficacy of combined topiramate/thioctic acid therapy in migraine prophylaxis. Saudi Pharm. J. 2010, 18, 239-243. [CrossRef]

110. Lea, R.; Colson, N.; Quinlan, S.; Macmillan, J.; Griffiths, L. The effects of vitamin supplementation and MTHFR (C677T) genotype on homocysteine-lowering and migraine disability. Pharmacogenet. Genom. 2009, 19, 422-428. [CrossRef]

111. Menon, S.; Lea, R.A.; Roy, B.; Hanna, M.; Wee, S.; Haupt, L.M.; Oliver, C.; Griffiths, L.R. Genotypes of the MTHFR C677T and MTRR A66G genes act independently to reduce migraine disability in response to vitamin supplementation. Pharmacogenet. Genom. 2012, 22, 741-749. [CrossRef]

112. Prousky, J.; Seely, D. The treatment of migraines and tension-type headaches with intravenous and oral niacin (nicotinic acid): Systematic review of the literature. Nutr. J. 2005, 4, 3. [CrossRef]

113. Chiu, H.-Y.; Yeh, T.-H.; Huang, Y.-C.; Chen, P.-Y. Effects of Intravenous and Oral Magnesium on Reducing Migraine: A Meta-analysis of Randomized Controlled Trials. Pain Physician 2016, 19, E97-E112.

114. Kudin, A.P.; Debska-Vielhaber, G.; Vielhaber, S.; Elger, C.E.; Kunz, W.S. The mechanism of neuroprotection by topiramate in an animal model of epilepsy. Epilepsia 2004, 45, 1478-1487. [CrossRef]

115. Motaghinejad, M.; Motevalian, M.; Shabab, B. Neuroprotective effects of various doses of topiramate against methylphenidate induced oxidative stress and inflammation in rat isolated hippocampus. Clin. Exp. Pharmacol. Physiol. 2016, 43, 360-371. [CrossRef]

116. Wilkes, J.J.; Nelson, E.; Osborne, M.; Demarest, K.T.; Olefsky, J.M. Topiramate is an insulin-sensitizing compound in vivo with direct effects on adipocytes in female ZDF rats. Am. J. Physiol. Endocrinol. Metab. 2005, 288, E617-E624. [CrossRef]

117. Tripathi, G.M.; Kalita, J.; Misra, U.K. A study of oxidative stress in migraine with special reference to prophylactic therapy. Int. J. Neurosci. 2018, 128, 318-324. [CrossRef]

118. Li, R.; Liu, Y.; Chen, N.; Zhang, Y.; Song, G.; Zhang, Z. Valproate Attenuates Nitroglycerin-Induced Trigeminovascular Activation by Preserving Mitochondrial Function in a Rat Model of Migraine. Med. Sci. Monit. 2016, 22, 3229-3237. [CrossRef]

119. Sitarz, K.S.; Elliott, H.R.; Karaman, B.S.; Relton, C.; Chinnery, P.F.; Horvath, R. Valproic acid triggers increased mitochondrial biogenesis in POLG-deficient fibroblasts. Mol. Genet. Metab. 2014, 112, 57-63. [CrossRef] 
120. Kashiwaya, Y.; Takeshima, T.; Mori, N.; Nakashima, K.; Clarke, K.; Veech, R.L. D-beta-hydroxybutyrate protects neurons in models of Alzheimer's and Parkinson's disease. Proc. Natl. Acad. Sci. USA 2000, 97, 5440-5444. [CrossRef]

121. Milder, J.; Patel, M. Modulation of oxidative stress and mitochondrial function by the ketogenic diet. Epilepsy Res. 2012, 100, 295-303. [CrossRef]

122. Prins, M.L.; Lee, S.M.; Fujima, L.S.; Hovda, D.A. Increased cerebral uptake and oxidation of exogenous betaHB improves ATP following traumatic brain injury in adult rats. J. Neurochem. 2004, 90, 666-672. [CrossRef]

123. Tieu, K.; Perier, C.; Caspersen, C.; Teismann, P.; Wu, D.-C.; Yan, S.-D.; Naini, A.; Vila, M.; Jackson-Lewis, V.; Ramasamy, R.; et al. D-beta-hydroxybutyrate rescues mitochondrial respiration and mitigates features of Parkinson disease. J. Clin. Investig. 2003, 112, 892-901. [CrossRef]

124. Bough, K. Energy metabolism as part of the anticonvulsant mechanism of the ketogenic diet. Epilepsia 2008, 49 (Suppl. 8), 91-93. [CrossRef]

125. Srivastava, S.; Kashiwaya, Y.; King, M.T.; Baxa, U.; Tam, J.; Niu, G.; Chen, X.; Clarke, K.; Veech, R.L. Mitochondrial biogenesis and increased uncoupling protein 1 in brown adipose tissue of mice fed a ketone ester diet. FASEB J. 2012, 26, 2351-2362. [CrossRef]

126. Zhao, Z.; Lange, D.J.; Voustianiouk, A.; MacGrogan, D.; Ho, L.; Suh, J.; Humala, N.; Thiyagarajan, M.; Wang, J.; Pasinetti, G.M. A ketogenic diet as a potential novel therapeutic intervention in amyotrophic lateral sclerosis. BMC Neurosci. 2006, 7, 29.

127. Kelman, L. The Triggers or Precipitants of the Acute Migraine Attack. Cephalalgia 2007, $27,394-402$. [CrossRef]

128. Borkum, J.M. Migraine Triggers and Oxidative Stress: A Narrative Review and Synthesis. Headache 2015. [CrossRef]

129. Welch, K.M.; Nagesh, V.; Aurora, S.K.; Gelman, N. Periaqueductal gray matter dysfunction in migraine: Cause or the burden of illness? Headache 2001, 41, 629-637. [CrossRef]

130. Gonullu, H.; Gonullu, E.; Karadas, S.; Arslan, M.; Kalemci, O.; Aycan, A.; Sayin, R.; Demir, H. The levels of trace elements and heavy metals in patients with acute migraine headache. J. Pak. Med. Assoc. 2015, 65, 694-697.

131. Alp, R.; Selek, S.; Alp, S.I.; Taşkin, A.; Koçyiğit, A. Oxidative and antioxidative balance in patients of migraine. Eur. Rev. Med. Pharmacol. Sci. 2010, 14, 877-882.

132. Aytaç, B.; Coşkun, Ö.; Alioğlu, B.; Durak, Z.E.; Büber, S.; Tapçi, E.; Öcal, R.; İnan, L.E.; Durak, İ.; Yoldaş, T.K. Decreased antioxidant status in migraine patients with brain white matter hyperintensities. Neurol. Sci. 2014, 35, 1925-1929. [CrossRef]

133. Bernecker, C.; Ragginer, C.; Fauler, G.; Horejsi, R.; Möller, R.; Zelzer, S.; Lechner, A.; Wallner-Blazek, M.; Weiss, S.; Fazekas, F.; et al. Oxidative stress is associated with migraine and migraine-related metabolic risk in females. Eur. J. Neurol. 2011, 18, 1233-1239. [CrossRef]

134. Bolayir, E.; Celik, K.; Kugu, N.; Yilmaz, A.; Topaktas, S.; Bakir, S. Intraerythrocyte antioxidant enzyme activities in migraine and tension-type headaches. J. Chin. Med. Assoc. 2004, 67, 263-267.

135. Ciancarelli, I.; Tozzi-Ciancarelli, M.; Massimo, C.D.; Marini, C.; Carolei, A. Urinary Nitric Oxide Metabolites and Lipid Peroxidation By-Products in Migraine. Cephalalgia 2003, 23, 39-42. [CrossRef]

136. Ciancarelli, I.; Tozzi-Ciancarelli, M.; Spacca, G.; Massimo, C.D.; Carolei, A. Relationship Between Biofeedback and Oxidative Stress in Patients With Chronic Migraine. Cephalalgia 2007, 27, 1136-1141. [CrossRef]

137. Eren, Y.; Dirik, E.; Neşelioğlu, S.; Erel, Ö. Oxidative stress and decreased thiol level in patients with migraine: Cross-sectional study. Acta Neurol. Belg. 2015, 115, 643-649. [CrossRef]

138. Geyik, S.; Altunısık, E.; Neyal, A.M.; Taysi, S. Oxidative stress and DNA damage in patients with migraine. J. Headache Pain 2016, 17, 10. [CrossRef]

139. Gumusyayla, S.; Vural, G.; Bektas, H.; Neselioglu, S.; Deniz, O.; Erel, O. A novel oxidative stress marker in migraine patients: Dynamic thiol-disulphide homeostasis. Neurol. Sci. 2016, 37, 1311-1317. [CrossRef]

140. Shimomura, T.; Kowa, H.; Nakano, T.; Kitano, A.; Marukawa, H.; Urakami, K.; Takahashi, K. Platelet Superoxide Dismutase in Migraine and Tension-Type Headache. Cephalalgia 1994, 14, 215-218. [CrossRef]

141. Tozzi-Ciancarelli, M.; De Matteis, G.; Di Massimo, C.; Marini, C.; Ciancarelli, I.; Carolei, A. Oxidative Stress and Platelet Responsiveness in Migraine. Cephalalgia 1997, 17, 580-584. [CrossRef] 
142. Tuncel, D.; Tolun, F.I.; Gokce, M.; İmrek, S.; Ekerbiçer, H. Oxidative Stress in Migraine with and Without Aura. Biol. Trace Elem. Res. 2008, 126, 92-97. [CrossRef]

143. Yilmaz, G.; Sürer, H.; Inan, L.E.; Coskun, O.; Yücel, D. Increased nitrosative and oxidative stress in platelets of migraine patients. Tohoku J. Exp. Med. 2007, 211, 23-30. [CrossRef]

144. Neri, M.; Frustaci, A.; Milic, M.; Valdiglesias, V.; Fini, M.; Bonassi, S.; Barbanti, P. A meta-analysis of biomarkers related to oxidative stress and nitric oxide pathway in migraine. Cephalalgia 2015, 35, 931-937. [CrossRef]

145. Palmirotta, R.; Barbanti, P.; De Marchis, M.L.; Egeo, G.; Aurilia, C.; Fofi, L.; Ialongo, C.; Valente, M.G.; Ferroni, P.; Della-Morte, D.; et al. Is SOD2 Ala16Val polymorphism associated with migraine with aura phenotype? Antioxid. Redox Signal. 2015, 22, 275-279. [CrossRef]

146. Saygi, S.; Erol, İ.; Alehan, F.; Yalçın, Y.Y.; Kubat, G.; Ataç, F.B. Superoxide Dismutase and Catalase Genotypes in Pediatric Migraine Patients. J. Child Neurol. 2015, 30, 1586-1590. [CrossRef]

147. Haces, M.L.; Hernández-Fonseca, K.; Medina-Campos, O.N.; Montiel, T.; Pedraza-Chaverri, J.; Massieu, L. Antioxidant capacity contributes to protection of ketone bodies against oxidative damage induced during hypoglycemic conditions. Exp. Neurol. 2008, 211, 85-96. [CrossRef]

148. Veech, R.L.; Bradshaw, P.C.; Clarke, K.; Curtis, W.; Pawlosky, R.; King, M.T. Ketone bodies mimic the life span extending properties of caloric restriction. IUBMB Life 2017, 69, 305-314. [CrossRef]

149. Maalouf, M.; Sullivan, P.G.; Davis, L.; Kim, D.Y.; Rho, J.M. Ketones inhibit mitochondrial production of reactive oxygen species production following glutamate excitotoxicity by increasing NADH oxidation. Neuroscience 2007, 145, 256-264. [CrossRef]

150. Achanta, L.B.; Rae, C.D. $\beta$-Hydroxybutyrate in the Brain: One Molecule, Multiple Mechanisms. Neurochem. Res. 2017, 42, 35-49. [CrossRef]

151. Kong, G.; Huang, Z.; Ji, W.; Wang, X.; Liu, J.; Wu, X.; Huang, Z.; Li, R.; Zhu, Q. The Ketone Metabolite $\beta$-Hydroxybutyrate Attenuates Oxidative Stress in Spinal Cord Injury by Suppression of Class I Histone Deacetylases. J. Neurotrauma 2017, 34, 2645-2655. [CrossRef]

152. Nagao, M.; Toh, R.; Irino, Y.; Mori, T.; Nakajima, H.; Hara, T.; Honjo, T.; Satomi-Kobayashi, S.; Shinke, T.; Tanaka, H.; et al. $\beta$-Hydroxybutyrate elevation as a compensatory response against oxidative stress in cardiomyocytes. Biochem. Biophys. Res. Commun. 2016, 475, 322-328. [CrossRef] [PubMed]

153. Shimazu, T.; Hirschey, M.D.; Newman, J.; He, W.; Shirakawa, K.; Le Moan, N.; Grueter, C.A.; Lim, H.; Saunders, L.R.; Stevens, R.D.; et al. Suppression of oxidative stress by $\beta$-hydroxybutyrate, an endogenous histone deacetylase inhibitor. Science 2013, 339, 211-214. [CrossRef]

154. Wang, X.; Wu, X.; Liu, Q.; Kong, G.; Zhou, J.; Jiang, J.; Wu, X.; Huang, Z.; Su, W.; Zhu, Q. Ketogenic Metabolism Inhibits Histone Deacetylase (HDAC) and Reduces Oxidative Stress After Spinal Cord Injury in Rats. Neuroscience 2017, 366, 36-43. [CrossRef] [PubMed]

155. Bae, H.R.; Kim, D.H.; Park, M.H.; Lee, B.; Kim, M.J.; Lee, E.K.; Chung, K.W.; Kim, S.M.; Im, D.S.; Chung, H.Y. $\beta$-Hydroxybutyrate suppresses inflammasome formation by ameliorating endoplasmic reticulum stress via AMPK activation. Oncotarget 2016, 7, 66444-66454. [CrossRef] [PubMed]

156. Jarrett, S.G.; Milder, J.B.; Liang, L.-P.; Patel, M. The ketogenic diet increases mitochondrial glutathione levels. J. Neurochem. 2008, 106, 1044-1051. [CrossRef]

157. Winesett, S.P.; Bessone, S.K.; Kossoff, E.H.W. The ketogenic diet in pharmacoresistant childhood epilepsy. Expert Rev. Neurother 2015, 15, 621-628. [CrossRef]

158. Winawer, M.R.; Connors, R. Evidence for a shared genetic susceptibility to migraine and epilepsy. Epilepsia 2013, 54, 288-295. [CrossRef]

159. Coppola, G.; Pierelli, F.; Schoenen, J. Habituation and migraine. Neurobiol. Learn. Mem. 2009, 92, $249-259$. [CrossRef]

160. Aurora, S.K.; Wilkinson, F. The brain is hyperexcitable in migraine. Cephalalgia Int. J. Headache 2007, 27, 1442-1453. [CrossRef]

161. Cestèle, S.; Scalmani, P.; Rusconi, R.; Terragni, B.; Franceschetti, S.; Mantegazza, M. Self-limited hyperexcitability: Functional effect of a familial hemiplegic migraine mutation of the Nav1.1 (SCN1A) $\mathrm{Na}+$ channel. J. Neurosci. 2008, 28, 7273-7283. [CrossRef]

162. Lang, E.; Kaltenhäuser, M.; Neundörfer, B.; Seidler, S. Hyperexcitability of the primary somatosensory cortex in migraine-A magnetoencephalographic study. Brain J. Neurol. 2004, 127, 2459-2469. [CrossRef] 
163. Boulloche, N.; Denuelle, M.; Payoux, P.; Fabre, N.; Trotter, Y.; Géraud, G. Photophobia in migraine: An interictal PET study of cortical hyperexcitability and its modulation by pain. J. Neurol. Neurosurg. Psychiatry 2010, 81, 978-984. [CrossRef]

164. Moulton, E.A.; Becerra, L.; Maleki, N.; Pendse, G.; Tully, S.; Hargreaves, R.; Burstein, R.; Borsook, D. Painful heat reveals hyperexcitability of the temporal pole in interictal and ictal migraine States. Cerebral Cortex 2011, 21, 435-448. [CrossRef]

165. Ducros, A.; Denier, C.; Joutel, A.; Cecillon, M.; Lescoat, C.; Vahedi, K.; Darcel, F.; Vicaut, E.; Bousser, M.G.; Tournier-Lasserve, E. The clinical spectrum of familial hemiplegic migraine associated with mutations in a neuronal calcium channel. New England J. Med. 2001, 345, 17-24. [CrossRef]

166. Ophoff, R.A.; Terwindt, G.M.; Vergouwe, M.N.; van Eijk, R.; Oefner, P.J.; Hoffman, S.M.; Lamerdin, J.E.; Mohrenweiser, H.W.; Bulman, D.E.; Ferrari, M.; et al. Familial hemiplegic migraine and episodic ataxia type-2 are caused by mutations in the Ca2+ channel gene CACNL1A4. Cell 1996, 87, 543-552. [CrossRef]

167. De Fusco, M.; Marconi, R.; Silvestri, L.; Atorino, L.; Rampoldi, L.; Morgante, L.; Ballabio, A.; Aridon, P.; Casari, G. Haploinsufficiency of ATP1A2 encoding the Na+/K+ pump alpha2 subunit associated with familial hemiplegic migraine type 2. Nat. Genet. 2003, 33, 192-196. [CrossRef]

168. Dichgans, M.; Freilinger, T.; Eckstein, G.; Babini, E.; Lorenz-Depiereux, B.; Biskup, S.; Ferrari, M.D.; Herzog, J.; van den Maagdenberg, A.M.J.M.; Pusch, M.; et al. Mutation in the neuronal voltage-gated sodium channel SCN1A in familial hemiplegic migraine. Lancet 2005, 366, 371-377. [CrossRef]

169. Anttila, V.; Stefansson, H.; Kallela, M.; Todt, U.; Terwindt, G.M.; Calafato, M.S.; Nyholt, D.R.; Dimas, A.S.; Freilinger, T.; Müller-Myhsok, B.; et al. Genome-wide association study of migraine implicates a common susceptibility variant on 8q22.1. Nat. Genet. 2010, 42, 869-873. [CrossRef]

170. Chasman, D.I.; Schürks, M.; Anttila, V.; de Vries, B.; Schminke, U.; Launer, L.J.; Terwindt, G.M.; van den Maagdenberg, A.M.J.M.; Fendrich, K.; Völzke, H.; et al. Genome-wide association study reveals three susceptibility loci for common migraine in the general population. Nat. Genet. 2011, 43, 695-698. [CrossRef]

171. Freilinger, T.; Anttila, V.; de Vries, B.; Malik, R.; Kallela, M.; Terwindt, G.M.; Pozo-Rosich, P.; Winsvold, B.; Nyholt, D.R.; van Oosterhout, W.P.J.; et al. Genome-wide association analysis identifies susceptibility loci for migraine without aura. Nat. Genet. 2012, 44, 777-782. [CrossRef]

172. Ferrari, M.D.; Klever, R.R.; Terwindt, G.M.; Ayata, C.; van den Maagdenberg, A.M.J.M. Migraine pathophysiology: Lessons from mouse models and human genetics. Lancet Neurol. 2015, 14, 65-80. [CrossRef]

173. Bough, K.J.; Rho, J.M. Anticonvulsant Mechanisms of the Ketogenic Diet. Epilepsia 2007, 48, 43-58. [CrossRef]

174. Yudkoff, M.; Daikhin, Y.; Melø, T.M.; Nissim, I.; Sonnewald, U.; Nissim, I. The ketogenic diet and brain metabolism of amino acids: Relationship to the anticonvulsant effect. Annu. Rev. Nutr. 2007, 27, 415-430. [CrossRef]

175. Ma, W.; Berg, J.; Yellen, G. Ketogenic diet metabolites reduce firing in central neurons by opening K(ATP) channels. J. Neurosci. 2007, 27, 3618-3625. [CrossRef]

176. Juge, N.; Gray, J.A.; Omote, H.; Miyaji, T.; Inoue, T.; Hara, C.; Uneyama, H.; Edwards, R.H.; Nicoll, R.A.; Moriyama, Y. Metabolic control of vesicular glutamate transport and release. Neuron 2010, 68, 99-112. [CrossRef]

177. Masino, S.A.; Li, T.; Theofilas, P.; Sandau, U.S.; Ruskin, D.N.; Fredholm, B.B.; Geiger, J.D.; Aronica, E.; Boison, D. A ketogenic diet suppresses seizures in mice through adenosine $\mathrm{A}_{1}$ receptors. J. Clin. Investig. 2011, 121, 2679-2683. [CrossRef]

178. Sada, N.; Lee, S.; Katsu, T.; Otsuki, T.; Inoue, T. Epilepsy treatment. Targeting LDH enzymes with a stiripentol analog to treat epilepsy. Science 2015, 347, 1362-1367. [CrossRef]

179. Won, Y.-J.; Lu, V.B.; Puhl, H.L.; Ikeda, S.R. $\beta$-Hydroxybutyrate Modulates N-Type Calcium Channels in Rat Sympathetic Neurons by Acting as an Agonist for the G-Protein-Coupled Receptor FFA3. J. Neurosci. 2013, 33, 19314-19325. [CrossRef]

180. Tanner, G.R.; Lutas, A.; Martínez-François, J.R.; Yellen, G. Single K ATP channel opening in response to action potential firing in mouse dentate granule neurons. J. Neurosci. 2011, 31, 8689-8696. [CrossRef]

181. Giménez-Cassina, A.; Martínez-François, J.R.; Fisher, J.K.; Szlyk, B.; Polak, K.; Wiwczar, J.; Tanner, G.R.; Lutas, A.; Yellen, G.; Danial, N.N. BAD-Dependent Regulation of Fuel Metabolism and KATP Channel Activity Confers Resistance to Epileptic Seizures. Neuron 2012, 74, 719-730. [CrossRef] 
182. Gerich, F.J.; Hepp, S.; Probst, I.; Müller, M. Mitochondrial inhibition prior to oxygen-withdrawal facilitates the occurrence of hypoxia-induced spreading depression in rat hippocampal slices. J. Neurophysiol. 2006, 96, 492-504. [CrossRef]

183. Takano, T.; Tian, G.-F.; Peng, W.; Lou, N.; Lovatt, D.; Hansen, A.J.; Kasischke, K.A.; Nedergaard, M. Cortical spreading depression causes and coincides with tissue hypoxia. Nat. Neurosci. 2007, 10, 754-762. [CrossRef]

184. Hoffmann, U.; Sukhotinsky, I.; Eikermann-Haerter, K.; Ayata, C. Glucose modulation of spreading depression susceptibility. J. Cereb. Blood Flow Metab. 2013, 33, 191-195. [CrossRef]

185. Kilic, K.; Karatas, H.; Dönmez-Demir, B.; Eren-Kocak, E.; Gursoy-Ozdemir, Y.; Can, A.; Petit, J.-M.; Magistretti, P.J.; Dalkara, T. Inadequate brain glycogen or sleep increases spreading depression susceptibility. Ann. Neurol. 2018, 83, 61-73. [CrossRef]

186. Peroutka, S.J. Neurogenic inflammation and migraine: implications for the therapeutics. Mol. Interv. 2005, 5, 304. [CrossRef]

187. Lukacs, M.; Tajti, J.; Fulop, F.; Toldi, J.; Edvinsson, L.; Vecsei, L. Migraine, Neurogenic Inflammation, Drug Development-Pharmacochemical Aspects. Curr. Med. Chem. 2017, 24, 3649-3665. [CrossRef]

188. Ramachandran, R. Neurogenic inflammation and its role in migraine. Semin. Immunopathol. 2018, 40, 301-314. [CrossRef]

189. Diener, H.-C.; Goadsby, P.; Asghar, M.; Hansen, A.; Kapijimpanga, T.; Edvinsson, L.; Warfvinge, K.; Olesen, J.; Diener, H. CGRP as a new target in prevention and treatment of migraine. Lancet. Neurol. 2014, 13, 1065-1067. [CrossRef]

190. Durham, P.L. Calcitonin Gene-Related Peptide (CGRP) and Migraine. Headache J. Head Face Pain 2006, 46, S3-S8. [CrossRef]

191. Goadsby, P.J.; Edvinsson, L.; Ekman, R. Vasoactive peptide release in the extracerebral circulation of humans during migraine headache. Ann. Neurol. 1990, 28, 183-187. [CrossRef]

192. Lassen, L.H.; Haderslev, P.A.; Jacobsen, V.B.; Iversen, H.K.; Sperling, B.; Olesen, J. CGRP may play a causative role in migraine. Cephalalgia Int. J. Headache 2002, 22, 54-61. [CrossRef]

193. Khan, S.; Olesen, A.; Ashina, M. CGRP, a target for preventive therapy in migraine and cluster headache: Systematic review of clinical data. Cephalalgia 2017, 39, 333102417741297. [CrossRef]

194. Yuan, H.; Lauritsen, C.G.; Kaiser, E.A.; Silberstein, S.D. CGRP Monoclonal Antibodies for Migraine: Rationale and Progress. BioDrugs 2017, 31, 487-501. [CrossRef]

195. Akerman, S.; Williamson, D.J.; Kaube, H.; Goadsby, P.J. The effect of anti-migraine compounds on nitric oxide-induced dilation of dural meningeal vessels. Eur. J. Pharmacol. 2002, 452, 223-228. [CrossRef]

196. Ashina, M.; Bendtsen, L.; Jensen, R.; Schifter, S.; Olesen, J. Calcitonin gene-related peptide levels during nitric oxide-induced headache in patients with chronic tension-type headache. Eur. J. Neurol. 2001, 8, 173-178. [CrossRef]

197. OLESEN, J. The role of nitric oxide (NO) in migraine, tension-type headache and cluster headache. Pharmacol. Ther. 2008, 120, 157-171. [CrossRef]

198. Olesen, J.; Ashina, M. Can nitric oxide induce migraine in normal individuals? Cephalalgia 2015, 35, 1125-1129. [CrossRef]

199. Boćkowski, L.; Smigielska-Kuzia, J.; Sobaniec, W.; Zelazowska-Rutkowska, B.; Kułak, W.; Sendrowski, K. Anti-inflammatory plasma cytokines in children and adolescents with migraine headaches. Pharmacol. Rep. 2010, 62, 287-291. [CrossRef]

200. Longoni, M.; Ferrarese, C. Inflammation and excitotoxicity: Role in migraine pathogenesis. Neurol. Sci. 2006, 27, s107-s110. [CrossRef]

201. Yılmaz, I.A.; Özge, A.; Erdal, M.E.; Edgünlü, T.G.; Çakmak, S.E.; Yalın, O.Ö. Cytokine Polymorphism in Patients with Migraine: Some Suggestive Clues of Migraine and Inflammation. Pain Med. 2010, 11, 492-497. [CrossRef]

202. Levy, D. Migraine pain, meningeal inflammation, and mast cells. Curr. Pain Headache Rep. 2009, 13, $237-240$. [CrossRef]

203. Youm, Y.-H.; Nguyen, K.Y.; Grant, R.W.; Goldberg, E.L.; Bodogai, M.; Kim, D.; D'Agostino, D.; Planavsky, N.; Lupfer, C.; Kanneganti, T.D.; et al. The ketone metabolite $\beta$-hydroxybutyrate blocks NLRP3 inflammasome-mediated inflammatory disease. Nat. Med. 2015, 21, 263-269. [CrossRef]

204. Shao, B.-Z.; Xu, Z.-Q.; Han, B.-Z.; Su, D.-F.; Liu, C. NLRP3 inflammasome and its inhibitors: A review. Front Pharmacol 2015, 6, 262. [CrossRef] 
205. Masino, S.A.; Ruskin, D.N. Ketogenic diets and pain. J. Child Neurol. 2013, 28, 993-1001. [CrossRef]

206. Ruskin, D.N.; Suter, T.A.C.S.; Ross, J.L.; Masino, S.A. Ketogenic diets and thermal pain: Dissociation of hypoalgesia, elevated ketones, and lowered glucose in rats. J. Pain 2013, 14, 467-474. [CrossRef]

207. Ruskin, D.N.; Kawamura, M.; Masino, S.A. Reduced pain and inflammation in juvenile and adult rats fed a ketogenic diet. PLoS ONE 2009, 4, e8349. [CrossRef]

208. Cámara-Lemarroy, C.R.; Rodriguez-Gutierrez, R.; Monreal-Robles, R.; Marfil-Rivera, A. Gastrointestinal disorders associated with migraine: A comprehensive review. World J. Gastroenterol. 2016, 22, 8149-8160. [CrossRef]

209. Hindiyeh, N.; Aurora, S.K. What the Gut Can Teach Us About Migraine. Curr. Pain Headache Rep. 2015, 19, 33. [CrossRef]

210. Van Hemert, S.; Breedveld, A.C.; Rovers, J.M.P.; Vermeiden, J.P.W.; Witteman, B.J.M.; Smits, M.G.; de Roos, N.M. Migraine associated with gastrointestinal disorders: Review of the literature and clinical implications. Front. Neurol. 2014, 5, 241. [CrossRef]

211. De Roos, N.M.; van Hemert, S.; Rovers, J.M.P.; Smits, M.G.; Witteman, B.J.M. The effects of a multispecies probiotic on migraine and markers of intestinal permeability-results of a randomized placebo-controlled study. Eur. J. Clin. Nutr. 2017, 71, 1455-1462. [CrossRef]

212. Straube, A.; Müller, H.; Stiegelbauer, V.; Frauwallner, A. [Migraine prophylaxis with a probiotic. Results of an uncontrolled observational study with 1020 patients]. MMW Fortschr. Med. 2018, 160, 16-21. [CrossRef]

213. Aydinlar, E.I.; Dikmen, P.Y.; Tiftikci, A.; Saruc, M.; Aksu, M.; Gunsoy, H.G.; Tozun, N. IgG-Based Elimination Diet in Migraine Plus Irritable Bowel Syndrome. Headache J. Head Face Pain 2013, 53, 514-525. [CrossRef]

214. Lindefeldt, M.; Eng, A.; Darban, H.; Bjerkner, A.; Zetterström, C.K.; Allander, T.; Andersson, B.; Borenstein, E.; Dahlin, M.; Prast-Nielsen, S. The ketogenic diet influences taxonomic and functional composition of the gut microbiota in children with severe epilepsy. NPJ Biofilms Microbiomes 2019, 5, 5. [CrossRef]

215. Zhang, Y.; Zhou, S.; Zhou, Y.; Yu, L.; Zhang, L.; Wang, Y. Altered gut microbiome composition in children with refractory epilepsy after ketogenic diet. Epilepsy Res. 2018, 145, 163-168. [CrossRef]

216. Olson, C.A.; Vuong, H.E.; Yano, J.M.; Liang, Q.Y.; Nusbaum, D.J.; Hsiao, E.Y. The Gut Microbiota Mediates the Anti-Seizure Effects of the Ketogenic Diet. Cell 2018, 173, 1728-1741.e13. [CrossRef]

217. Xie, G.; Zhou, Q.; Qiu, C.-Z.; Dai, W.-K.; Wang, H.-P.; Li, Y.-H.; Liao, J.-X.; Lu, X.-G.; Lin, S.-F.; Ye, J.-H.; et al. Ketogenic diet poses a significant effect on imbalanced gut microbiota in infants with refractory epilepsy. World J. Gastroenterol 2017, 23, 6164-6171. [CrossRef]

218. Newell, C.; Bomhof, M.R.; Reimer, R.A.; Hittel, D.S.; Rho, J.M.; Shearer, J. Ketogenic diet modifies the gut microbiota in a murine model of autism spectrum disorder. Mol. Autism 2016, 7, 37. [CrossRef]

219. Swidsinski, A.; Dörffel, Y.; Loening-Baucke, V.; Gille, C.; Göktas, Ö.; Reißhauer, A.; Neuhaus, J.; Weylandt, K.-H.; Guschin, A.; Bock, M. Reduced Mass and Diversity of the Colonic Microbiome in Patients with Multiple Sclerosis and Their Improvement with Ketogenic Diet. Front. Microbiol. 2017, 8, 1141. [CrossRef]

220. Tagliabue, A.; Ferraris, C.; Uggeri, F.; Trentani, C.; Bertoli, S.; de Giorgis, V.; Veggiotti, P.; Elli, M. Short-term impact of a classical ketogenic diet on gut microbiota in GLUT1 Deficiency Syndrome: A 3-month prospective observational study. Clin. Nutr. ESPEN 2017, 17, 33-37. [CrossRef]

221. Klement, R.J.; Pazienza, V. Impact of Different Types of Diet on Gut Microbiota Profiles and Cancer Prevention and Treatment. Medicina (Kaunas) 2019, 55, 84. [CrossRef]

222. Augustin, K.; Khabbush, A.; Williams, S.; Eaton, S.; Orford, M.; Cross, J.H.; Heales, S.J.R.; Walker, M.C.; Williams, R.S.B. Mechanisms of action for the medium-chain triglyceride ketogenic diet in neurological and metabolic disorders. Lancet Neurol. 2018, 17, 84-93. [CrossRef]

223. Gross, E.; Putananickal, N.; Orsini, A.-L.; Schmidt, S.; Vogt, D.R.; Cichon, S.; Sandor, P.; Fischer, D. Efficacy and safety of exogenous ketone bodies for preventive treatment of migraine: A study protocol for a single-centred, randomised, placebo-controlled, double-blind crossover trial. Trials 2019, 20, 61. [CrossRef]

(C) 2019 by the authors. Licensee MDPI, Basel, Switzerland. This article is an open access article distributed under the terms and conditions of the Creative Commons Attribution (CC BY) license (http:/ / creativecommons.org/licenses/by/4.0/). 